\title{
Reflections on Diaspora and Soft Power: Community Building among Female US Expats in Southern Europe
}

\author{
Irina Isaakyan and Anna Triandafyllidou
}

\begin{abstract}
Illuminated by life-stories of American women in Italy and Greece, our work examines a complex relationship between expatriate collectivity and soft power agency. The data were collected from in-depth interviews with 60 US-nationals who live in Italy and Greece. Our findings show that these women view shape as a strong diasporic collectivity through activities of ecological civic engagement, which, however, do not result in a successful exercise of soft power. The isolationist nature of their collectivity causes a number of diasporic mistakes and turns their chosen community project into a weak resource for soft power, a translation of which remains highly problematic.
\end{abstract}

\section{Key words:}

Civic engagement, community, diaspora, kinship, national identity, soft power 


\section{Introduction}

\section{Overview}

In the increasing volume of studies on diasporas' soft power, special emphasis is being placed on diasporic networks, through which expatriates often advocate the cultural and civic attractiveness of their home country and herein execute its soft power over the host society (Blarel 2008; Nye 2004, 2011; Watanabe 2008). An issue of concern is that not every ethnic community that has strong networks and speaks culturally and civically on behalf of its homeland can develop a strong agency of soft power (Dossani 2009; Gupta 2008; Nye 2008).

In this context, little is known about the diversity of cultural resources used by expatriates to influence attitudes and patterns of belonging to their country of origin in the native majority. In particular, there have been no studies on the soft power agency of American expatriates, although the United States remains the soft power world leader. Illuminated by the lives of American female migrants in Italy and Greece, our work examines a complex relationship between the expat collectivity and its soft power agency.

There are more than 250,000 US nationals living full-time in Italy and Greece, $60 \%$ of whom are women, the expat collectivity and group agency of which remain under-examined, nevertheless (Mills 2000; Smith 2010; Wennersten 2008). At the same time, studies of gender and nationalism acknowledge a robust general propensity of expatriate women for shaping collectivity through a number of ways including various forms of civic participation (Charsley 2012; Yuval-Davis 1998). It is important to note that civic engagement is said to be an essential feature of the American lifestyle and a strong source of transatlantic mobility and diasporic activities (Jennings 2002; Jespersen 2005; Mettler-Welsh 2004; Oldenburg 1989; Putnam 2000).

In this theoretical and empirical context we are interested in investigating how they use their cultural resources, their soft power, in ways that connect or oppose them to both homeland and host society or indeed in ways that they converge with the host society leading to new blends of identity and community.

\section{Methodology and structure}

This research is based on two years of extensive fieldwork in Italy and Greece, covering the time shift from September 2012 to August 2014. We conducted narrative biographic interviews with 60 US-nationals who had been living in Italy and Greece for the 
period between five and thirty years. To protect the identity of the informants, all of them appear under fictitious names while their real names and affiliations are never mentioned anywhere. The data are examined through the method of narrative analysis, which is used to provide insights into the process of transmitting the soft power as well as to uncover nuances of how the women see their own collectivity and national attractiveness.

The first part of the paper is a literature review on the concepts of "soft power" and "diaspora". In the second part of the paper, we present our findings by looking at activities of "ecological civic engagement", through which the informants' diasporic collectivity shapes. The paper finally discusses to what extent these activities relate to transmission of soft power, and shows a complex interplay between diaspora and community building on the one hand and issues of soft power and socio-cultural integration on the other hand.

\section{Theoretical background: Diaspora and its power}

\section{Soft power}

"Soft power" is a concept used in reference to "the country's co-optive power, which is its ability to shape preferences of other nations through cultural attraction and seduction". Soft power thus arises from "intangible, immaterial resources such as the country's culture, political ideas and ideologies" (Nye 2011, 31). Many cultural and ideological tools are consistently used by the world-leading states for transmitting their soft power including cinema, cultural exchanges or the world of fashion (Dossani 2009; Gupta 2008; Watanabe 2008). As the soft power world leader, the United States, in particular, has many resources that can potentially generate soft power (Nye 2004, 33). However, soft power transmission does not always mean its acquisition since emerging global idea-scapes are comprised of conflicting images. In the milieu of the over-abundant soft power devices, there is thus a danger of confusing soft power with imitation: in fact, wearing blue jeans or drinking CocaCola does not mean that people feel and make choices like Americans (Nye 2011).

\section{Diasporic collectivity}

The politics of soft power is in many cases closely linked to the diaspora politics as expat communities are expected to be strong agents of their homelands' soft power (Blarel 2008; Nye 2011). At the same time, scholars are worried that these cultural activities are not always translated to soft power and therefore often lead to diaspora's alienation from the host 
culture, even in spite of the diaspora's cultural attractiveness. Thus the role of cultural resources that a diaspora uses through its associations becomes a crucial point in diaspora politics.

Assessing the success of the diaspora politics (or the success of its soft power transmission), Shain (1999) distinguishes between "isolationist" and "integrationist diasporas" - or diasporic collectivities that respectively construct their group identities vis-àvis the host society and as part of it. Although the diasporic experience is often thought of in terms of "homeland nostalgia", it also conveys a relationship with the host society (Brubaker 2005; Cohen 2008; Tololyan 2007). The disporic revision of the communal past (including the in-group bonding) takes place within the context of the host culture and may, consequently, borrow a number of devices from the latter for its own reproduction (Sheffer 2003; Tololyan 2007). The "connecting" dynamics of the diaspora thus emerges as a compromise between the collective diasporic memory and the cultural practice of the host society (Cohen 2008). At the same time, the "contesting" nature of diaspora leads to cultural difference and identity conflict, raising the question of the "Other" (Ibid; Tololyan 2007). There are always certain features of the host society which diasporics are not ready to accept (Brubaker 2005; Sheffer 2003).

\section{The concept of civic engagement}

The diaspora dynamics takes place through encounters that physically unite people for example, the frequently mentioned expatriate experience of civic participation, whose link with soft power remains obscure (Brubaker 2005; Tololyan 2007; Triandafyllidou 2009). In the light of global changes and liberalisation discourses, the sociological understanding of civic engagement has been recently developed into a "market-oriented concept", which views civically involved people as responsible 'evaluators of public services' (Kaifeng \& Bergrud 2008, 29). Thus in North-American scholarship, civic engagement is now associated with a broad range of activities that express "experienced understanding of and emotional meaning to the ideas and spheres of public life" such as environmental protection (Levine 2012, 3). In reference with US-nationals, social civic engagement is especially emphasized as a driver of their lifestyle choices including migration to continental Europe, which is famous for its high concentration of civic life venues (Oldenburg 1989; Putnam 2000; Wennersten 2008). 


\section{The context of Southern Europe}

The strongest rival of the United States in soft power wars, Europe has been for many years globally attractive (Blarel 2008; Ney 2011). Within this soft power context, the ancient art/history and exquisite cuisines /landscapes of Southern Europe become highly magnetic for US-nationals (Trundle 2014). Although Italy and Greece remain America's strong transatlantic partners, Greece has been characterised by a high level of the post-World War II anti-Americanism, which stands in contrast with the Italian public opinion (Ambrosini 2011; Stavridis 2007; Stefanidis 2007). An important detail is that both countries have stable systems of patriarchy, with the marginalization of female immigrants on the job market and in the household (Isaakyan \& Triandafyllidou 2014).

In the light of these contradictory forces (both supportive and disruptive of expatriate collectivity and soft power), it seems reasonable to ask to what extent female US expatriates in Italy and Greece form a diasporic collectivity and how they use their cultural resources for soft power within the local context.

\section{Findings}

\section{The civic engagement of American expatriate women}

Candace, who is 67 years old, lives in Naples together with her husband. She grew up in Colorado and moved to Naples together with her husband eight years ago because they both had been offered positions as civilian nurses in the Navy base near Naples.

In Naples, Candace has been involved for a long time in volunteer work for an organization that provides veterinary services for the local metro-area. The founder of this organization is an American veterinarian who strikes to persuade Italians to join her campaign against stray animals. The company owner asks local people to trap stray dogs and cats; and then to bring them to her clinic, where she would neuter them and give them for adoption. Thus by controlling the reproduction of stray animals in the South of Italy, the clinic owner tries to contribute to environmental protection.

Candace eagerly joined the stray-animal prevention campaign soon after her retirement from the Navy hospital. For almost five years, she had been volunteering in this clinic every day on a full-time basis. A qualified nurse, Candace helps to neuter these 
animals: she is responsible for their post-operation care. She looks after them when they awake from anaesthesia and checks that they should not choke. She also helps the clinic to find potential foster homes for such animals. Although she is not paid for this work, her professional skills of a paediatric nurse are irreplaceable in this clinic.

Candace admits that local people do not share their perspectives at all. In many cases, environmental protection remains the matter of concern for American and other Anglophone expatriates rather than for Italians. Candace notes that Italians very seldom trap stray animals or adopt them after sterilization. In the majority of cases, such animals are spotted and later fostered by American women themselves, who do that as part of their "save-theenvironment" programmes.

Her younger co-national Miriam, who is 43 , is one of the ardent proponents of the environmental project in Greece. She lives in a Greek town with her Greek husband and two children. Miriam was born in California in 1969 - 'in quite a hippie year', as she herself notes. Her both parents were hippies, who never married. When she was very little, they separated - that is, 'just stopped living together'. Miriam was eleven when her drug-addicted mother was denied parental rights for child negligence and the girl was consequently placed with a foster family, which she later changed a couple of times.

As she admits, she spent her pre-adolescence and all her teenage years 'not in a very clean area in Long Beach, moving from people to people and without a precise idea of what a cosy living place could be'. After she had married her Greek husband, they moved to his country of origin.

Now all her friends are exclusive American women who are also the wives of local Greek - men. They have an informal club called "Red Hats", foundered by Miriam. Now its members engage in activities of environmental protection such as cleaning beaches and local streets or taking care of the street garbage. The members of this club are recognised by the red hats they wear during such activities (aka the Little Red Riding Hood).

Miriam is concerned with the fact that the streets in Greece are polluted. The lifestories of Miriam and Candace - as well as of the other informants - show that the basic framework for their expatriate associational life is the idea of "civic duty", which is for them synonymous with "the outside ecology" or "environmental protection". Their cleaning, or 
ecological, activities include a number of volunteer behaviours that are very popular in the United States, for example: cleaning public roads and beaches from garbage; public toilet cleaning; and stray animal clinics. Some of these activities demand a certain degree of professionalism [e.g.: Candace' involvement in the veterinary clinic] while many others do not require more than "just the common sense of and a very basic respect to your own living space" (as they themselves believe).

One of the most popular ecological activities is the DR Road Project (frequently advertised in US mass media):

Ruby: ${ }^{1}$ Have you ever heard about the Doctor Road? In America there are groups of people who "adapt the road". They go along a chosen road periodically as a group with bags and pick up the trash. Here I was trying to adapt the road between the town and the beach. Italian people thought I was crazy.

The ecological activities are conducted in groups - when club members split into small groups and make a schedule of cleaning a road, a beach or a street or of patrolling the supermarket usually on a monthly or weekly basis (however, sometimes more regularly). In a smaller place (where Miriam lives), such activities may be conducted every other day as part of the expatriate women's daily routine.

At the same time, such activities are also delivered as 'individual home assignments' that is, individually by an expatriate woman:

Violet: ${ }^{2}$ When I pass by a dustbin every morning, I see hundreds of bags scattered around the street. I just pick five of them and put them into the bin.

Our informants admit that their daily "prolific pastime activities" such as jogging or reading books together always incorporate ecological civic duty activities [e.g.: cleaning roads while jogging] in order to make the civic duty more culturally attractive - . Through expatriate blog writing, Miriam and other women advertise their ecological projects and recruit new expat participants.

\footnotetext{
${ }^{1}$ Ruby (age 65) is a retired US designer from Washington DC, who is now solo-living in the Italian province of Umbria.

${ }^{2}$ Violet (age 37) is a medical researcher who is married to an Italian man and now lives in Sicily.
} 
Their sense of community - or their sense of who they are - is thus inseparable from their sense of ecological civic duty or from their ecological obligations. "We are a principle-based community - a principle-based diaspora", says June (an American from Athens).

\section{Collectivity shaping: Civic engagement and diaspora}

The ecological engagement becomes the main resource of their shaping as a diaspora. The connecting dynamics of their diasporic formation points to their strong connectivity with the USA and its national values, which they summarise - or over-generalize, to be more precise, - as "civic engagement" or "civic duty". During their various "wive-club" events, they use their diasporic imagination in order to ideologically re-conceptualize their civic behaviours within a broader, more historical, context.

June: When we, American house-wives [the wives of Greek men] get together in the evenings to discuss an American book, we choose one that would touch upon certain civic values such as taking care of the environment and discuss how important it is to take care of the abandoned garden or of the people around us. Using such small examples of civic duty, we remind ourselves of the importance of remaining American here.

Their imaginative thinking and actual - environmental - politicisation reinforce each other, thus creating rather complex commemoration structures. They "we"-conceptualise themselves as "we-Americans" while "to be American" means to be civically responsible, environmentally protective and having broader horizons upon one's living space.

However, they commemorate their homeland routine by using the cultural resources of Greece and Italy, whose ancient buildings and "divine landscapes" are among the plenty of cultural devices that trigger their sense of civic duty. They themselves admit that in the US they were not so civically active as here because in Italy and Greece there are many more historical things to protect and to save from pollution. As Penelope from Sardinia says, "When I see all this dirt floating on the indigo sea-surface, I feel very sad because this is the air we breathe every evening. My sense of civic duty does not allow me to tolerate this. I never thought about this while living near the polluted part of the Niagara Falls in the New York state”.

Their desire to "clean" or to "ecologically protect" Italian and Greek cities thus points to their connectivity with these countries although they disagree with the mentality of the local people. The perceived civic negligence of Greek and Italian people is the core of the informants' 
contestation dynamics. This is something that they believe they will never be able to accept. As Ruby positions herself in response to their environmental negligence, "I am deeply frustrated when I see how negligent they are about littering their streets and their beautiful landscapes".

The contestation is added by the Janus-faced organization of the Italian/Greek living space, in which emphasis is placed on protecting one's own house but at the sake of a wider communal space:

Violet: $\quad$ There tons of garbage bags scattered around where I live. I think if everyone picks at least one bag and puts it into the bin, there would not be rubbish in the streets anymore. But they all think: "No, it is not my job. And I am not going to do this!" But this is your town! This is the place where you live! They walk their dogs and always leave the crap around. So everything is so crappy!

Candace: $\quad$ They would clean their house every day and make the floor polish. At the same time, they would not think twice before throwing their garbage into the street from their cars. This is kind of mentality "I don't want to care about what is going on beyond my family and beyond my house" is what I always find very depressing.

Candace notes that Italians do not only lack civic-duty attitudes and behaviours but they also refuse to learn them or to understand the consequences of their absence. She thus conceptualises them as civic-duty illiterate. For American women, they therefore become the irresponsible and passive national Other, who is not the master of his own destiny and is a negative artefact of the overall beautiful landscape:

They do not want to take any responsibility for controlling the reproduction of stray animals and consequently for controlling the preservation of their beautiful nature. Everything is given its natural course, which should not be that way. Italians are very irresponsible in this sense. They have a very weak sense of civic duty.

Thus for American women, Greeks and Italians become and remain the "They" - that is, seen as negligent to nature (environmentally unfriendly) and civic-duty illiterate. While understanding their own collective essence as that of a self-regulating and consciously organised "civic duty diaspora", American women conceptualise Greek and Italian people as "principle-free" or "duty-free nations". 
In fact, their civic engagement finds little resonance in the Italian/Greek local population and does not become a strong instrument for soft power. The American obsession with cleaning streets is understood as "foreignness" or "oddity" by Italians and Greeks, who are far from being persuaded to develop identical patterns of behaviour:

Violet: I cleaned the street and it just ended littered again.

Ruby: When I was cleaning the road to the beach, local people thought I was mentally ill.

Miriam: I often hear from local people in the street, "You are definitely a foreigner: a Greek would never do anything like this." They often come to watch us cleaning the stuff in the street or cleaning after our dogs in the park because this is what they themselves have never done or seen. For them, this is like a pay-free show.

However, the national Other is actually becoming much broader than the host society. Their overseas ecological project fosters a rather over-exaggerated homeland commemoration and alienates them also from their co-nationals back home. In ecological activities, American female expatiates do what they would never do at home. For example, Miriam (who grew up in the polluted district of Long Beach and who never had a stable clean home) or Naomi (who grew up in Bronx) are obsessed with cleaning streets in Greece. So is Candace keen on the animal clinics while in the US she never had a pet in her house.

\section{Discussion: The soft power dissonance}

-Who do all these well-fed homeless dogs belong to?

-They are not homeless. They live here, in the Temple of Zeus.

-A very ecological approach to one's historical monuments!

-But human history was never clean! Do you seriously believe that in the Ancient Greece there were no stray dogs? They are part of our history too.

(From the conversation between an American tourist and the Greek guide from Acropolis, November 2013.)

\section{Phantom power}

The earlier mentioned studies of soft power prove that it is successfully exercised when the object of attraction has a symbolic meaning for the audience, which is never stable. In a number of his works, Nye further shows that soft power resources do not always convert 
into the real power with a desired outcome because of the public confusion around their symbolism. The cultural attractiveness of the United States has a complex structure - it has many levels such as sex, violence and materialism on the one hand yet openness, mobility, pluralism and freedom at the other end of the continuum (Nye 2004, 106).

When many objects stand for the symbolism of a more complex object such as "Americanness", it may be difficult to distinguish which symbol is important and which is not. The diverse imagery of the American video culture creates false images or phantasms [e.g.: rough sex and violence], whose exotics is more robust; while real images [e.g.: hard work and civic duty] are either less exotic or less known to the general public.

Within this tapestry of conflicting images, such a specific symbol of Americanness as civic engagement remains unknown to other cultures because overshadowed in public discourses. At the same time, the mass media on both sides of the Atlantic continue to propagate false images associated with the US, thus facilitating a transmission of phantom soft power. As Miriam notes:

Most Italians I know think of America as a country of rough sex, hard rock and non-stop swearing - the way it is portrayed in movies. They have no idea that we clean our streets every day. They may believe that they love America - but this is like loving a ghost that does not exist. We are not the nation of Hollywood they expect us to be - we are the middle-class Americans they don't actually know. We are ordinary American people with a very strong sense of civic duty, about which they have never heard, and they just refuse to understand what it is. It is very difficult to bring home to them who we are and to make them love us for who we are.

Our informants stress that, in their daily expatriate lives, they always encounter various salient resources of phantom soft power, which cause false attachments and identities in local people. As Miriam notes, "the local television is overabundant with false images of what Americans are like; and every time I approach my neighbours, they look at me as if I were Geena Davis or Nicole Kidman and refuse to understand what the hack I am doing with their garbage." It is very difficult for middle-class expatriate Americans to refute the soft power of Hollywood, which "is not as clean as Harvard but nevertheless further reaching" (Nye 2004, 47). 


\section{Serving the community?}

Our findings show that the community that American expatriate women aim to serve through their civic engagement is not the same as the community in which Italian and Greek people actually live and to which Americas should seek their integration. According to Janning and colleagues $(1999,55)$, "the semantics of the word 'community' in America is very much different from the cultural traditions in Europe". While the European community is viewed as mostly bound to the close-knit neighbourhood of the family institute, the American understanding is more related to a wider space where kin-unrelated people share common identities. It is "based on empathic interaction, which is achieved by residing in the same locality", which is both physically and culturally much broader than the family neighbourhood or the family network (ibid, 100).

The interviewees therefore perceive the kinship-oriented communities in Italy and Greece as "civically impaired" and "claustrophobic":

Miriam: $\quad$ Greek people live entirely within their extended families. They do not want to get to know people outside their homes.

Violet: $\quad$ They don't want to work together to help their society to improve because they just do not understand what a wider society is.

Candace: If something is not inside their house, it is not within their control.

The informants attribute the claustrophobic nature of the Italian/Greek community to the overall impact of patriarchy, whose wider structures dictate family patterns and other cultural practices of socialisation. The interviewed women believe that it is the hegemonic masculinity that prevents Italian and Greek people from trapping stray dogs and submitting them for future neutralization as well as from accepting neutered animals in their houses:

Candace: $\quad$ Italians have a weak sense of civic duty: they are obsessed with patriarchy and with the idea of being a man to such an extent that they would prefer intact animals.

In the opinion of Candace, the ideas of "patriarchy" and "civic duty" are intrinsically incompatible as patriarchy supplants wider spaces of democracy by causing their contraction. However, a number of studies on community and citizenship imply that, at the same time, such patriarchal structures often create other spaces of democracy that may be in a direct opposition to the American ideals and suggested gentrification, thus leading toward a 
"community" conception much more complex than if explained in terms of patriarchy (Donaldson \& Kymlicka 2011; Fried 1962; Gans 1983).

Theoretically, the idea of ecological civic engagement may sound positive if we forget that community is actually more than the wellbeing of people only. In practice, a community is, however, a complex socio-cultural and ecological system that consists of both human and non-human elements including non-human citizens and symbolic, meaningful objects (Donaldson \& Kymlicka 2011).

For Americans, community is civically constructed on western democratic principles, which go beyond kinship while, at the same time, neglecting certain routines and relationships with non-humans that are meaningful for Greeks, Italians and other kinnetworked actors. As the interviews show, the Italian/Greek model of (kinship) community (which Americans conceptualize as "civically illiterate") includes feral animals "as cocitizens in mixed human-animal democratic polis" entitled for the rights of membership and authentic reproduction in a shared cooperative scheme. ${ }^{3}$ Thus for Italians and Greeks, the feral animal welfare is an essential part of their community, which also enriches their sense of history.

Unlike Americans, Italians and Greeks live amidst their ancient and medieval history and preserve historical niches in which there is a place for liminal animal denizens. The guide working in the Temple of Zeus cannot imagine this historical site without stray dogs. Wellfed and sometimes hefty, these liminal animal denizens peacefully rest in or walk along Acropolis and Pompei, making an essential part of the local community of humans and animals, of which Greeks and Napolitanos are very proud. "Why not let them be here, if they there is so much space and if they do not hurt anyone?", says the guide from the Temple of Zeus, 'Our real history was never clean - it is not a snow souvenir that you can buy in the airport'. Therefore, the suggested slum clearance and further domestication of feral animals threatens to destroy the existing historical niches and to disrupt the continuity between the past and the present in the consciousness of Italian and Greek people.

\footnotetext{
${ }^{3}$ Viewing domesticated animals as co-citizens requires seeing them as "having the right of their subjective good". For more on "human-animal citizenship", see Donaldson and Kymlicka (2011).
} 


\section{Conclusion}

Our findings show that the major cultural resource that supports the expatriate collectivity of our informants is ecological engagement, which is widely promoted through their networks and interest-clubs in the countries of their destination. Dynamic public actors, US-national women in Italy and Greece organize and sustain a large array of ecological social activities within their expatriate communities, through which they connect to and contest their home and host societies and consequently shape as a diasporic entity. Their civic engagement makes them a very strong, culturally congruent and culturally reproductive diasporic segment that is, nevertheless, failing to exercise the soft power on behalf of its country of origin.

Despite its strong emphasis on improving the community life through a better ecology, the American model of civic engagement is something that local Greek and Italian people do not associate with "being American", regardless of an overall proAmerican or antiAmerican public opinion. The effect on the host society is that of a culture shock: "Geena Davis cleaning the garbage". Added by the disruption of continuity, the surprise turns to be rather negative, leading to the rejection of offered "American" values or the soft power failure.

While enriching a scholarly understanding of diaspora dynamics and contributing to the development of a comprehensive diaspora model, our case intrinsically contradicts traditional theories of diaspora and soft power, which tend to apply these two concepts in parallel. Our work shows that the cultural resources for diaspora building can become soft power only if they tie into the cultural idioms of the host society.

The way in which female US expats frame their community and view themselves as a diaspora is not in tune with the Greek and Italian national identity repertoires. For Greeks and Italians, national identity is built on ethnic or national cultural features and not on social civic values. Thus the feeling of alienation of US expats and their effort to influence their Greek and Italian neighbours comes across as a personal trait, a strange habit of $\mathrm{X}$ or $\mathrm{Y}$ rather than as a way of life and a collectivity. 
This different view on what community is becomes the key barrier for the diaspora's exercise of soft power in the host society. It points to the fact that cultural resources used for community building need to be intelligible to the host community for any soft power to be exercised. To the extent that the host community perceives other features to be the dominant ones for defining "community" and associates the diaspora with very different traits (global geopolitical and cultural hegemon), the soft power cannot go through as it stumbles upon the phantom Americanness and the different conceptions of national community of local Greeks and Italians.

\section{References}

Ambrosini, Maurizio. 2013. "Immigration in Italy: Between Economic Acceptance and Political Rejection”. Journal of International Migration and Integration 14(1): 175-194.

Antwi-Boateng, Osman. 2011. "After War than Peace: The US-Based Liberian Diaspora as Peace-Building Norm Entrepreneurs', Journal of Refugee Studies 25(1): 93-112.

Antwi-Boateng, Osman. 2012. "The Transformation of the US-Based Liberian Diaspora from Hard Power to Soft Power Agents." African Studies Quarterly 13 (1/2): 55-74.

Baker, Paul. 1964. The Fortunate Pilgrims. Cambridge, MA: Harvard University Press.

Blarel, Nicolas. 2012. “India's Soft Power: From Potential to Reality?”. In India: The Next Superpower?, edited by Mukulika Banerjee. London, UK: LSE IDEAS. Accessed on 20 November 2013. http://www.lse.ac.uk/IDEAS/publications/reports/pdf/SR010/blarel.pdf.

Brubaker, Rodgers. 2005. “The 'Diaspora' Diaspora”. Ethnic and Racial Studies 28(1): 119.

Charsley, Katherine. 2012. Transnational Marriage. London/New York: Routledge.

Cohen, Robin. 2008. Global Diasporas: An Introduction, Revised $2^{\text {nd }}$ Edition. London/New York: Routledge.

Donaldson, Susan and Will Kymlicka. 2011. Zoopolis. Oxford, UK: Oxford University Press.

Dossani, Rafiq. 2009. "Indian Soft Power and Association of the American Diaspora", Stanford Program on Regions of Innovation and Entrepreneurship. Available at: http://iisdb.stanford.edu/pubs/22997/Indian_Soft_Power_\%26_Diaspora_Associations_Nov09-1.pdf.

Fechter, Ann-Marie. 2016. Transnational Lives: Expatriates in Indonesia. London: Routledge. 
Freedman, Lawrence. 2001. The Cold War: A Military History. London, UK: Cassell \& Co.

Fried, Marc. 1963. "Grieving For a Lost Home". In Urban Renewal, edited by James Wilson, 3590379. Cambridge, MA: MIT Press.

Gans, Herb. 1982. The Urban Villagers. New York: Free Press.

Gupta, Additi. 2008. “Commentary on India's Soft Power and Diaspora”. International Journal on World Peace 25(3): 61-68.

Isaakyan, Irina, and Anna Triandafyllidou. 2014. "Anglophone Marriage-Migrants in Southern Europe: A Study of Expat nationalism and Integration." International Review of Sociology 24(3): 374-390. doi: 10.1080/03906701.2014.954333.

Janning, Josef, Charles Kupchan, and Dirk Rumberg. 1999. Civic Engagement in the Atlantic Community. Gütersloh, Germany: Bertelsmann Foundation Publishers.

Jennings, Kent. 2002. "Generation Units and the Student Protest Movement in the United States”. Political Psychology 23(2): 303-324.

Jespersen, Christopher. 2005. “Analogies at War: Vietnam, the Bush Administration's War in Iraq, and the Search for a Usable Past". Pacific Historical Review 74(3): 411-426.

Kaifeng, Yang and Eric Bergrund. 2008. Civic Engagement in a Network Society. Charlotte, NC: Information Age Publishing.

Kiy, Richard and Anne McEnany. 2010. "Civic Engagement, Volunteerism and Charitable Giving: Americans Retiring in Mexico's Coastal Communities”. International Community Foundation Press 06/2010.

Knight, Roger. 2001. "A Sugar Factory and Its Swimming Oool: Incorporation and Differentiation in Dutch Colonial Society in Java". Ethnic and Racial Studies 24(3): 451-471.

Levine, David. 2011. The Capacity for Civic Engagement: Public and Private Worlds of the Self. Basingstoke: Palgrave Macmillan.

Mettler, Susan and Eric Welch. 2004. "Civic Generation: Policy Feedback Effects of the GI Bill on Political Involvement over the Life Course". British Journal of Political Studies 34: 497-518.

Mills, Karen. 2000. Americans Overseas in U.S. Censuses. Washington, DC: Bureau of the Census.

Nye, Joseph. 2004. Soft Power: The Means to Success in World Politics. New York: Public Affairs.

Nye, Joseph. 2008. The Powers to Lead. Oxford, UK: Oxford University Press.

Nye, Joseph. 2011. The Future of Power. Philadelphia, PA: Perseus Books. 
Oldenburg, Ray. 1989. The Great Good Place. New York: Paragon House.

Putnam, Robert. 1993. Making Democracy Work. Princeton, NJ: Princeton University Press.

Putnam, Robert. 2000. Bowling Alone: The Collapse and Revival of American Community.

New York/London: Simon \& Schuster.

Shain, Yossi. 1999. Marketing the American Creed Abroad: Diasporas in the U.S. and Their Homelands. Cambridge, UK: Cambridge University Press.

Sheffer, Gabriel. 2003. Diaspora Politics: At Home Abroad. Cambridge, UK: Cambridge University Press.

Simmel, George. 1955. Conflict and the Web of Group Affiliations. New York: Free Press.

Smith, Claire. 2010. "These are our Numbers: Civilian Americans Overseas and Voter Turnout." OVF Research Newsletters 2(4).

https://www.overseasvotefoundation.org/files/counting\%20american\%20civilians\%20abroad. pdf.

Stoler, Ann Laura. 2002. Carnal Knowledge and Imperial Power: Race and the Intimate in Colonial Rule. Berkeley, CA: University of California Press.

Stavridis, Stelios. 2007. “Anti-Americanism in Greece” (Paper \#6). Hellenic Observatory Papers on Greece and Southeast Europe.

http://www.lse.ac.uk/europeanInstitute/research/hellenicObservatory/pdf/GreeSE/GreeSE06. pdf.

Stefanidis, Ioannis. 2007. Stirring the Greek Nation: Political Culture, Irredentism and AntiAmericanism in Post-War Greece, 1945-1967. Aldershot: Ashgate.

Tololyan, Khachiq. 2007. "The Contemporary Discourse of Diaspora Studies". Comparative Studies of South Asia, Africa and the Middle East 27(3): 647-855.

Triandafyllidou, Anna. 2009. "Sub-Saharan African Immigrant Activists in Europe: Transcultural Capital and Transcultural Community Building”. Ethnic and Racial Studies 32(1): 93-116.

Trundle, Catherine. 2014. Americans in Tuscany: Charity, Compassion and Belonging. New York: Berghahn.

Watanabe, Yasushi. 2008. “Anti-Americanism in Japan”. In Soft Power Superpowers, edited by Yasushi Watanabe and David McConnell, 3-17. New York: M.E. Sharp.

Wennersten, John. 2008. Leaving America: The New Expatriate Generation. Santa Barbara, CA: Praeger. 
Yuval-Davis, Nira. 1998. Gender and Nation. Thousand Oaks, CA: Sage. 